\title{
Quality Improvement of a Small Water Supply

\author{
A Practical Application of a Full System of Nanofiltration
}

\author{
Rafael Marín Galvín \\ Control de Calidad, Calidad y Medio Ambiente \\ Empresa Municipal de Aguas de Córdoba, S.A. \\ Córdoba (Spain) \\ rmargal@emacsa.es
}

\author{
José Miguel Rodríguez Mellado \\ Dept. Química Física y Termodinámica Aplicada \\ Universidad de Córdoba \\ E-14014-Córdoba (Spain) \\ jmrodriguez@uco.es
}

\begin{abstract}
The THM level in the Spanish drinking water is limited to less than $0.100 \mathrm{mg} / \mathrm{L}$, due to its potential toxicological effect on humans. This paper investigates the comparison of the results obtained in a small supply of water that historically presented THM contents out of the Spanish normative, versus the results there obtained when the treatment was modified with the inclusion of a nanofiltration system. So, the conventional treatment first applied was that of pre-oxidation with chlorine and/or $\mathrm{KMnO}_{4}$, followed by coagulation with aluminum salts directly on closed sand filter, and disinfection final by chlorination: with this system, THM levels lower than $0.100 \mathrm{mg} / \mathrm{L}$ were not always secured. Thus, to improve the water quality, a full system of nanofiltration was implemented, after the above treatment, consisting in: pre-filtration through cartridges, filtration over activated carbon, post-filtration for retaining impurities, and finally, nanofiltration and chlorination of water after nanofiltration. In this order, the new treatment scheme has usually produced water with maximum THM levels of 0.058 $\mathrm{mg} / \mathrm{L}$, and average values of $0.013 \mathrm{mg} / \mathrm{L}, 0.30 \mathrm{mg} / \mathrm{L}$ for organic matter concentrations, and water always microbiologically pure. Also, the contents of $\mathrm{Fe}, \mathrm{Mn}$ and $\mathrm{Al}$ in the treated water were significantly reduced with respect to the previous situation without nanofiltration.
\end{abstract}

Keywords: nanofiltration; activated carbon; trihalometanes; water treatment plant (WTP); water supply

\section{INTRODUCTION}

The current normative for drinking water in Spain (RD 140/2003) establishes the content in trihalomethanes (THM) in water for public distribution as a parameter of special interest $[1,2]$. So, by considering the potential toxic impact of this type of compounds on the health of consumers [3], the limitation of the total THM concentration to a maximum value of $100 \mu \mathrm{g} / \mathrm{L}$ was established from January 1, 2009. This value must be respected in all drinking water in Spain in order to be qualified as safe and clean, i.e. as drinking water.

The generation of trihalomethanes is linked, among other causes, to the presence in the water of their precursors, in general aromatic polyphenolic compounds originated from degradation of biological material (especially vegetable materials). Chemical reactions between such precursors and the chlorine added to water for the treatments are the responsible for the formation of THM in waters subject to chlorination [1, $2,4,5]$.

In this way, the most important factors related with the THM generation in chlorinated waters are the following:

- Number and type of organic molecules present in the water.

- Type and amount of halogens other than chloride present in the water. So, the action of chlorine provokes the oxidation of these halogens different of chlorides and subsequently, the formation of bromine and iodine THM of high toxicological effect on humans.

- Chlorine applied dose: the higher the chlorine added, the higher the THM generation rate.

- Water temperature: higher temperatures increase the rate of THM formation.

- $\mathrm{pH}$ : alkaline values of the water favor the formation of chloroform, especially.

- Presence of catalysts: Fe and mainly Mn are very abundant in the majority of raw waters intended for treatment, and they can increase the practical speed of THM formation.

- Contact time between chlorine and water: as the time is increasing the THM level also increase. In this way, the highest rate of THM formation is given during the first 24-25 hours of chlorine-water contact [6-8].

In this regard, the practical formation rate of THM in waters is investigated using the known THM formation potential test, which consists of raw water chlorination with given levels of chlorine and the subsequent measurement of THM compounds formed along the reaction time [6-8].

With this information one can assess the most effective strategy for each particular supply to minimize the content of THM in drinking water. Summarizing, all available strategies may include the following [5, 9-11]:

\section{A. In the pre-oxidation step:}

- Total or partial replacement of chlorine used in the treatment of raw water. When the applied chlorine is lower, the THM formation is also reduced. 
- Use of alternative oxidants to chlorine, especially $\mathrm{KMnO}_{4}$, $\mathrm{ClO}_{2}$ and $\mathrm{O}_{3}$. It is sufficiently proved that substitution of chlorine by the above reactants forms sensibly lower THM levels [5-11].

- Use of activated carbon (powdered or by filtration bed). In this case, the adsorbent capacity of carbon can remove organic matter and THM precursors of the raw water at the beginning of the treatment. Moreover, when the water has already been chlorinated, activated carbon can also remove THM initially formed in the system.

\section{B. In the coagulation-flocculation-sedimentation step:}

- Use of more active coagulants than those conventionally employed in water clarification, such as different types of aluminum polychlorides and other similar ones. Thus, the reduction of organic matter amount in water could lead logically to lower THM formation with the same applied dose of chlorine.

- By changing the hydraulic and the design of decanters. This effect can affect the reaction time between organic matter and chlorinated water.

\section{In the disinfection step:}

- By replacing conventional chlorination disinfection by chloramines or $\mathrm{ClO}_{2}$. Production of THM is sensibly lower compared to when disinfectants are used [6-8].

\section{Apllication of non-conventional steps:}

- Use of membrane filtration techniques: nanofiltration and reverse osmosis, especially [12]. In this sense, it is known that the systems of nanofiltration or reverse osmosis have included units of ultrafiltration and adsorption with activated carbon prior nanofiltration and osmosis, to lead its correct function. In theses cases, the finished water can be finally chlorinated without any THM problem.

According to the above, the valid strategy for each case is defined by the specific type of raw water, the previous design of each WTP or treatment available, the distribution network, and the technical and economic capacity of the supply.

The aim of this paper is to present the yielding achieved with the implementation of a full nanofiltration system in a small water supply, which was troubled in meeting parametric levels of trihalomethanes, when the treatment was carried out by conventional pre-oxidation by chlorine and/or $\mathrm{KMnO}_{4}$, coagulation-flocculation, filtration on sand and final disinfection by chlorination.

\section{MATERIALS AND METHODS}

Dates here presented are referred to the water treatment system without nanofiltration and with nanofiltration. So, the studied period begins with the effective implementation of the nanofiltration system, from January $1^{\text {st }}$ and ends on October $31^{\text {st }} 2012$, i.e. 10 months of continuous operation, during which sampling was carried out on a weekly basis.
Three types of samples were taken each week: the first one was raw water intended for treatment and emanating from the Guadalmellato reservoir (Córdoba) [13, 14]; the second one corresponded to water after the conventional treatment of preoxidation, coagulation-flocculation, filtration and final chlorination; and the third one was water after the full treatment, i.e., pre-oxidation, coagulation-flocculation, filtration, nanofiltration and final chlorination: this finished water was distributed to the public.

Determinations of the quality parameters in water were carried out according to the usual standard water quality control methods:

- Color and turbidity were investigated by colorimetry; $\mathrm{pH}$ and conductivity with the corresponding electrodes;

- Free chlorine, iron, manganese, nitrite and ammonium by visible spectrophotometry using, respectively, DPD, $\alpha, \alpha^{\prime}-$ bipyridyl and ammonium thioglycolate, formaldoxime in basic medium, Zambelli method, and Nessler method (without distillation).

- Organic matter was quantified as potassium permanganate oxidizability; and hardness and bicarbonate levels were measured by volumetric titration $[15,16]$.

- The aluminum determination was made with the ICP technique (inductively coupled plasma) without previous digestion of the sample and for the measurement of trihalomethanes (THM) gas chromatography with microautomatic solid phase extraction and subsequent detection by electron capture was used. THM data correspond to the sum of chloroform, bromoform, bromo-dichloromethane and dibromo-chloromethane $[15,16]$.

- Finally, the determinations of Escherichia coli and total coliform were made by filtration through a membrane of $0.45 \mu \mathrm{m}$ pore size and incubation with chromogenic culture medium for 48 hours at $37^{\circ} \mathrm{C}$ to permit the development of colonies of potential microorganisms present in the water $[15,16]$.

\section{RESULTS AND DISCUSSION}

Water uptake for the small supply $\left(<10 \mathrm{~m}^{3}\right.$ of average daily consumption) comes from the Guadalmellato reservoir (located about $25 \mathrm{~km}$ from Cordoba, Spain). Table I presents the characteristics of water quality during our study. It should be noted that water has an acceptable organoleptic quality, conductivity and moderate saline contents, and middle hardness. Its main problem is the microbiological content, which sometimes reaches very important recounts, especially during the rainy season and subsequent runoff water to the reservoir $[13,14]$.

In addition, ammonia and manganese concentrations can be elevated, while the concentration of organic matter is moderate. In this sense, without being specially high in absolute terms, it is true that the origin of water from a reservoir with a high rate of algal presence (middle degree of eutrophication) during very few months of the year, favors the generation of THM in water after chlorination, especially in spring and autumn. 
TABLE I. UNTREATED RAW WATER CHARACTERISTICS (GUADALMELLATO RESERVOIR-CÓRDOBA, SPAIN).

\begin{tabular}{|c|c|c|c|c|}
\hline Parameter & Units & Max. & Min. & Mean \\
\hline Color & mg/L Pt-Co & 19 & 6 & 10 \\
\hline Turbidity & UNF & 7.7 & 1.7 & 4.2 \\
\hline pH & $\mathrm{pH}$ units & 7.75 & 7.36 & 7.50 \\
\hline Conductivity & $\mu \mathrm{S} / \mathrm{cm}$ & 284 & 251 & 267 \\
\hline Hardness & $\mathrm{mg} / \mathrm{L} \mathrm{CaCO}_{3}$ & 125 & 50 & 104 \\
\hline Bicarbonates & $\mathrm{mg} / \mathrm{L} \mathrm{HCO}_{3}^{-}$ & 141 & 116 & 126 \\
\hline Manganese & $\mu \mathrm{g} / \mathrm{L}$ & 995 & 52 & 293 \\
\hline Iron & $\mu \mathrm{g} / \mathrm{L}$ & 213 & 18 & 85 \\
\hline Nitrites & $\mathrm{mg} / \mathrm{L}$ & 0.084 & 0.006 & $<0.005$ \\
\hline Ammonia & $\mathrm{mg} / \mathrm{L}$ & 0.383 & $<0.020$ & 0.110 \\
\hline $\begin{array}{c}\text { Permanganate } \\
\text { Oxidability }\end{array}$ & $\mathrm{mg} / \mathrm{L} \mathrm{O}_{2}$ & 4.8 & 2.8 & 3.5 \\
\hline $\begin{array}{c}\text { Total } \\
\text { coliforms }\end{array}$ & colonies/100 mL & 5000 & 4 & 674 \\
\hline $\begin{array}{c}\text { Escherichia } \\
\text { coli }\end{array}$ & colonies/100 mL & 600 & 0 & 70 \\
\hline
\end{tabular}

Figure 1 shows the tests carried out to investigate at laboratory scale the potential of THM generation in the raw water by chlorination, by using two variables: applied chlorine dose (from $1 \mathrm{mg} / \mathrm{L}$ to $8 \mathrm{mg} / \mathrm{L}$ ) and contact time water-chlorine (up to 120 hours) maintaining a given chlorine dose $(3 \mathrm{mg} / \mathrm{L})$.
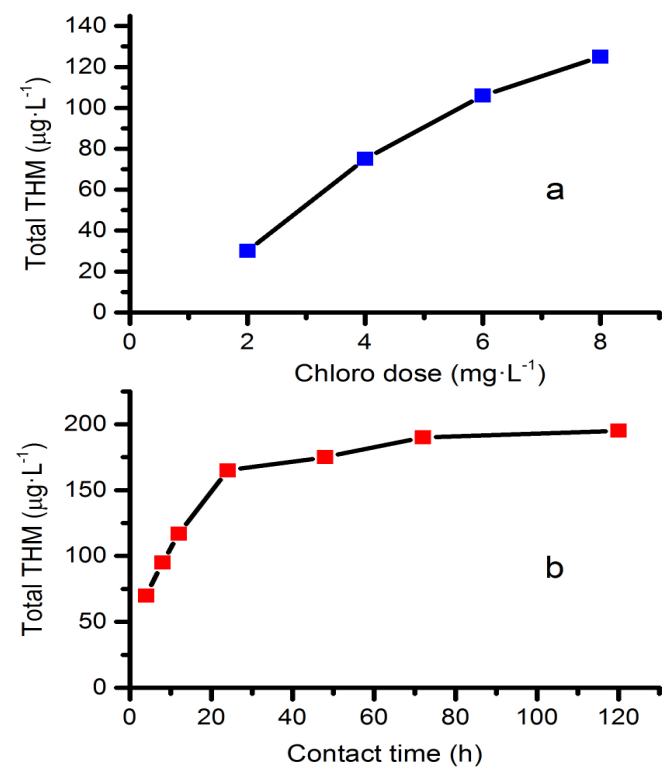

Fig. 1. THM formation from raw water as a function of: a) Chlorine dose, contact time $=2 \mathrm{~h}$; b) water-chlorine contact time, chlorine dose $=3 \mathrm{mg} / \mathrm{L}$.

Figure 1a indicates that the higher the dose of chlorine, the higher the THM formation. Thus, an increase of four times in the chlorine dose is associated to an increase of the same level in the production of THM: so, dosages of $2 \mathrm{~g} / \mathrm{m}^{3}$ of chlorine generated around $30 \mu \mathrm{g} / \mathrm{L}$ of THM, and dosages of $8 \mathrm{~g} / \mathrm{m}^{3}$ of chlorine produced around $125 \mu \mathrm{g} / \mathrm{L}$ of THM.

At the same time, Figure 1b shows that THM formation increases quickly up to more than $150 \mu \mathrm{g} / \mathrm{L}$ after 24 hours of contact time water-chlorine while the production is much more slower after the first 24 hours, as it has been stated in the bibliography [6-8].

By observing Figure 1 we can conclude that the dosage of about $5 \mathrm{mg} / \mathrm{L}$ chlorine (a quantity relatively frequent in the common water treatment) generated amounts of THM very close to $100 \mu \mathrm{g} / \mathrm{L}$ after only two hours of contact (Figure 1a) while contact times of only 8 hours with $3 \mathrm{mg} / \mathrm{L}$ chlorine dose caused a similar effect (Figure 1b). In addition, contact times of 24 hours were associated to production of THM levels higher than $150 \mu \mathrm{g} / \mathrm{L}$. All these information is very valuable to establish the industrial treatment of raw water.

On the other hand, the usual purification treatment of raw water before the implementation of nanofiltration was the following:

- Pre-oxidation with potassium permanganate (solid product previously dissolved in water).

- Pre-chlorination ( $\mathrm{NaClO}$ solution).

- Coagulation and subsequently filtration on sand filters by using commercial aluminium polyclhoride.

- Final disinfection before the distribution of water to the public, with commercial sodium hypochlorite solution.

The doses of all reactants were always adjusted depending on the practical operative results obtained in each moment, which varied accordingly the quality of the incoming raw water received in plant [5-8].

In this way, the practical reactants doses used during our study were the following:

- Pre-oxidation: $\mathrm{KMnO}_{4}$ solution with dosages ranging from 0 to $0.8 \mathrm{~g} / \mathrm{m}^{3}$.

- Pre-chlorination: $\mathrm{NaClO}$ solution with dosages expressed as chlorine ranging from 1.5 to $3.5 \mathrm{~g} / \mathrm{m}^{3}$.

- Coagulation-flocculation on closed sand filter: aluminium polychloride commercial solution ranging from 45 to 60 $\mathrm{g} / \mathrm{m}^{3}$, expressed as commercial product.

- Disinfection final: $\mathrm{NaClO}$ solution with non-variant dosages expressed as chlorine of $1.5 \mathrm{~g} / \mathrm{m}^{3}$.

In the most past of the sampling carried out along the 10 months of the survey, the applied treatment achieved treated water of high quality, with modest levels of $\mathrm{Mn}, \mathrm{Fe}$, nitrites and ammonia, but showing occasionally problems of concentrations of manganese out of limits, light microbiological occurrence not specifically pathogenic, and especially, a total THM levels over-passing the limiting values.

During these episodes of production of water out of normative, which can't be distributed to the supply (as established the Spanish normative -RD 140/2003-) the 
practical alternative was the use of cisterns. This implied additional difficulty and economical over.

As a complementary data, Table II presents the chemical and microbiological characteristics of finished water subjected to conventional treatment, i.e. before nanofiltration, along our study.

TABLE II. TREATED WATER CHARACTERISTICS AFTER THE TREATMENT WITH FILTRATION (WHITOUT NANOFILTRATION)

\begin{tabular}{|c|c|c|c|c|c|}
\hline Parameter & Units & Limits $^{a}$ & Maximum & Minimum & Mean \\
\hline Color & $\begin{array}{l}\mathrm{mg} / \mathrm{L} \\
\mathrm{Pt}-\mathrm{Co}\end{array}$ & 15 & 3.4 & $<0.2$ & 0.7 \\
\hline Turbidity & UNF & 5 & 0.76 & 0.02 & 0.23 \\
\hline $\mathrm{pH}$ & $\mathrm{pH}$ units & $6.5-9.5$ & 7.71 & 7.33 & 7.56 \\
\hline Conductivity & $\mu \mathrm{S} / \mathrm{cm}$ & 2500 & 319 & 132 & 274 \\
\hline $\begin{array}{l}\text { Residual free } \\
\qquad \mathrm{Cl}_{2}\end{array}$ & $\mathrm{mg} / \mathrm{L}$ & $0.2-1.0$ & 1.75 & $<0.05$ & 0.9 \\
\hline Hardness & $\begin{array}{c}\mathrm{mg} / \mathrm{L} \\
\mathrm{CaCO}_{3}\end{array}$ & (c) & 118 & 49 & 99 \\
\hline Bicarbonates & $\begin{array}{c}\mathrm{mg} / \mathrm{L} \\
\mathrm{HCO}_{3}^{-}\end{array}$ & (c) & 126 & 65 & 114 \\
\hline Manganese & $\mu \mathrm{g} / \mathrm{L}$ & 50 & 108 & $<10$ & 21 \\
\hline Iron & $\mu \mathrm{g} / \mathrm{L}$ & 200 & 57 & $<5$ & 12 \\
\hline Nitrites & $\mathrm{mg} / \mathrm{L}$ & 0.500 & 0.030 & $<0.005$ & 0.009 \\
\hline Ammonia & $\mathrm{mg} / \mathrm{L}$ & 0.500 & 0.033 & $<0.020$ & $<0.020$ \\
\hline Aluminum & $\mathrm{mg} / \mathrm{L}$ & 0.200 & 0.10 & 0.02 & 0.05 \\
\hline $\begin{array}{l}\text { Oxidability } \\
\text { to } \mathrm{KMnO}_{4}\end{array}$ & $\mathrm{mg} / \mathrm{L} \mathrm{O}_{2}$ & 5.0 & 2.2 & 0.3 & 1.6 \\
\hline Total THM ${ }^{\mathrm{b}}$ & $\mu \mathrm{g} / \mathrm{L}$ & 100 & 282 & 30 & 131 \\
\hline $\begin{array}{c}\text { Total } \\
\text { coliforms }\end{array}$ & $\begin{array}{c}\text { colonies/ } \\
100 \mathrm{~mL}\end{array}$ & 0 & $25^{(\mathrm{d})}$ & 0 & $3^{(\mathrm{d})}$ \\
\hline $\begin{array}{c}\text { Escherichia } \\
\text { coli }\end{array}$ & $\begin{array}{c}\text { colonies/ } \\
100 \mathrm{~mL}\end{array}$ & 0 & $5^{(\mathrm{d})}$ & 0 & $<1^{(\mathrm{d})}$ \\
\hline
\end{tabular}

a) From RD. 14/2003. b) After water chlorination. c) Not contemplated in RD. d) Total coliforms and Escherichia coli were only detected in 2 sampling of all the carried out: thus, the mean values are affected by these two samplings.

In this way, the maximum value column indicates manganese problems (more than $50 \mu \mathrm{g} / \mathrm{L}$ ), occurrence of total coliforms and Escherichia coli (more than 1 colony by filtering $100 \mathrm{~mL}$ of water -these positive results were tested in only 2 samplings of all the ones carried out-) and levels of total THM very much higher than the imperative parametric value of 100 $\mu \mathrm{g} / \mathrm{L}$ (up to $282 \mu \mathrm{g} / \mathrm{L}$ ). Moreover, the mean value of total THM also over-passed the parametric limit.

This previous situation became both a potential sanitary problem and a potential incidence of parametric nonobservance of the Spanish normative (RD 140/2003) in this supply. Raised the question, the Empresa Municipal de Aguas de Córdoba S.A. as responsible of above supply, and the Córdoba University laboratory evaluated several options in order to have a full treatment to ensure, except eventualities, adequate quality in all times.
In this regard, Figure 2 shows the known ability of separation associated to the industrial filtration techniques available $[5,10,12]$. Due to fact that we want to specially remove THM precursors (colloids), unspecific organic matter and microorganisms, implementation of a nanofiltration system could be found as a suitable solution.

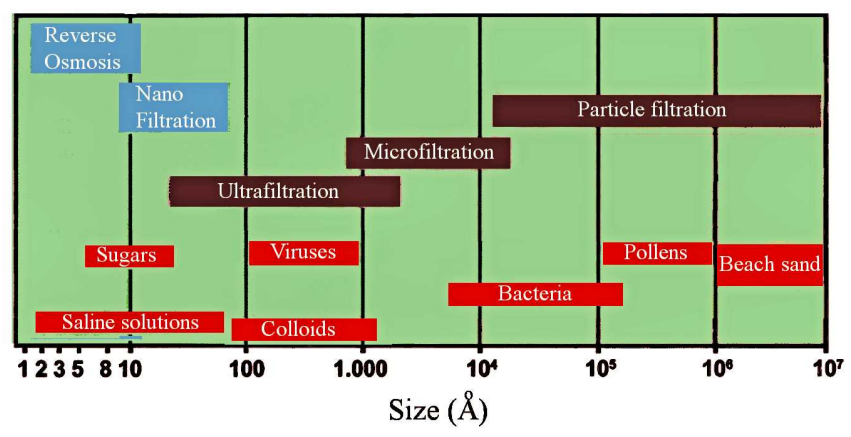

Fig. 2. Filtration spectrum and filtration capacity of the different techniques available.

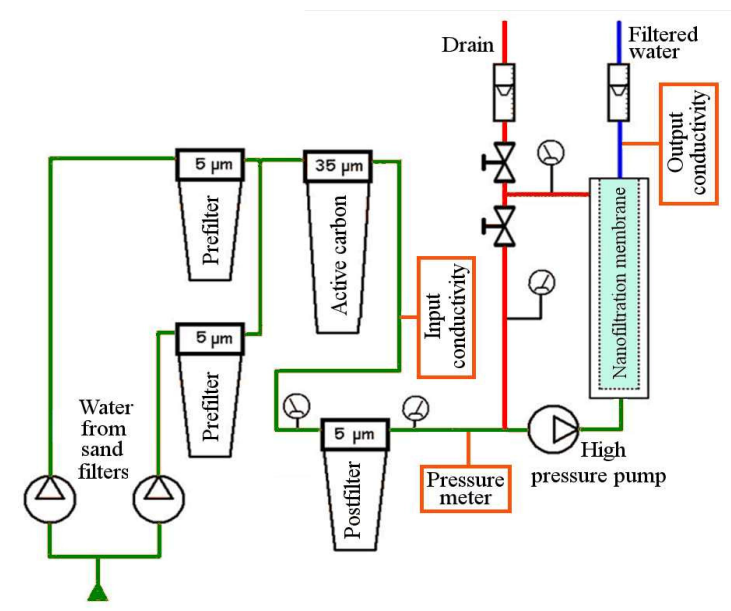

Fig. 3. Internal scheme of the full nanofiltration system.

Thus, a full nanofiltration system commercially available (supplied by KÄRCHER ${ }^{\mathrm{TM}}$ ) [17] was installed to treat the water produced from the conventional treatment (pre-oxidation and coagulation in closed sand filter). In this sense, the water was subjected to the following inner line process, as reflected in Figure 3:

- Pre-filtration through cartridges with particle retention capacity equal to or greater than $5 \mu \mathrm{m}$.

- Activated carbon filtration for the adsorption of varied organic compounds, including those associated with phenomena of occurrence of odor-taste in the treated water.

- Post-filtration, after the activated carbon filter, for retention of impurities which could be unfavorable to the nanofiltration membranes.

- Nanofiltration. In this sense, nanofiltration is the last phase in the removing of organic matter, colloids, THM precursors 
and formed THM, as well as microorganisms (bacteria and viruses) in the water [5, 6-9]. Nanofiltration membranes have a pore size of $<2 \mathrm{~nm}$, and all the substances and molecules lower than the above size should be retained in the system.

- Final chlorination of treated water for distribution to consumers.

The full system of integrated water treatment (i.e., prefiltering, adsorption by activated carbon, post-filtering and nanofiltration) has also a continuous residual chlorine analyzer to regulate the level of chlorination in treated water, considering the imperative value $\left(0.2\right.$ to $1.0 \mathrm{mg} / \mathrm{L}$ of $\left.\mathrm{Cl}_{2}\right)$.

Another complementary information is that treated water after nanofiltration could not be chlorinated to allow us some uses outside direct consumption, such as irrigation and gardening.

Finally, after the installation of nanofiltration was effective and optimization time was reached, data of quality treated water without and with nanofiltration were obtained to compare the two situations along the period studied.

In order to the above said, Tables II and III provide a comparative yield pattern obtained with the two available treatment processes. In this regard, the priority is the performance with respect to the removal of organic matter and the subsequent generation of THM in chlorinated water.

TABLE III. TREATED WATER CHARACTERISTICS AFTER NANOFILTRATION

\begin{tabular}{|c|c|c|c|c|c|}
\hline Parameter & Units & Limits $^{\boldsymbol{a}}$ & Maximum & Minimum & Mean \\
\hline Color & $\begin{array}{c}\mathrm{mg} / \mathrm{L} \\
\mathrm{Pt}-\mathrm{Co}\end{array}$ & 15 & 0.50 & $<0.02$ & 0.03 \\
\hline Turbidity & $\mathrm{UNF}$ & 5 & 0.24 & 0.02 & 0.07 \\
\hline $\mathrm{pH}$ & $\mathrm{pH}$ units & $6.5-9.5$ & 8.05 & 7.05 & 7.63 \\
\hline Conductivity & $\mu \mathrm{S} / \mathrm{cm}$ & 2500 & 281 & 108 & 177 \\
\hline $\begin{array}{c}\text { Residual free } \\
\mathrm{Cl}_{2}\end{array}$ & $\mathrm{mg} / \mathrm{L}$ & $0.2-1.0$ & 0.26 & $<0.05$ & $<0.05$ \\
\hline $\begin{array}{c}\text { Hardness } \\
\mathrm{mg} / \mathrm{L} \\
\mathrm{CaCO}_{3}\end{array}$ & $(\mathrm{c})$ & 80 & 43 & 53 \\
\hline Bicarbonates & $\begin{array}{c}\mathrm{mg} / \mathrm{L} \\
\mathrm{HCO}{ }^{-}\end{array}$ & $(\mathrm{c})$ & 98 & 58 & 72 \\
\hline Manganese & $\mu \mathrm{g} / \mathrm{L}$ & 50 & 45 & $<10$ & 15 \\
\hline Iron & $\mu \mathrm{g} / \mathrm{L}$ & 200 & 56 & $<5$ & 15 \\
\hline Nitrites & $\mathrm{mg} / \mathrm{L}$ & 0.500 & 0.049 & $<0.005$ & 0.010 \\
\hline Ammonia & $\mathrm{mg} / \mathrm{L}$ & 0.500 & 0.075 & $<0.020$ & $<0.020$ \\
\hline Aluminum & $\mathrm{mg} / \mathrm{L}$ & 0.200 & 0.07 & 0.02 & 0.04 \\
\hline $\begin{array}{c}\text { Oxidability } \\
\text { to KMnO }\end{array}$ & $\mathrm{mg} / \mathrm{L} \mathrm{\textrm {O } _ { 2 }}$ & 5.0 & 1.0 & $<0.1$ & 0.3 \\
\hline Total THM & $\mu \mathrm{bg} / \mathrm{L}$ & 100 & 58 & $<10$ & 13 \\
\hline
\end{tabular}

a) From RD. 14/2003. b) After water chlorination. c) Not contemplated in RD.

Moreover, in Figure 4a the extreme and mean values of organic matter in the raw, filtered and nanofiltered water are given.
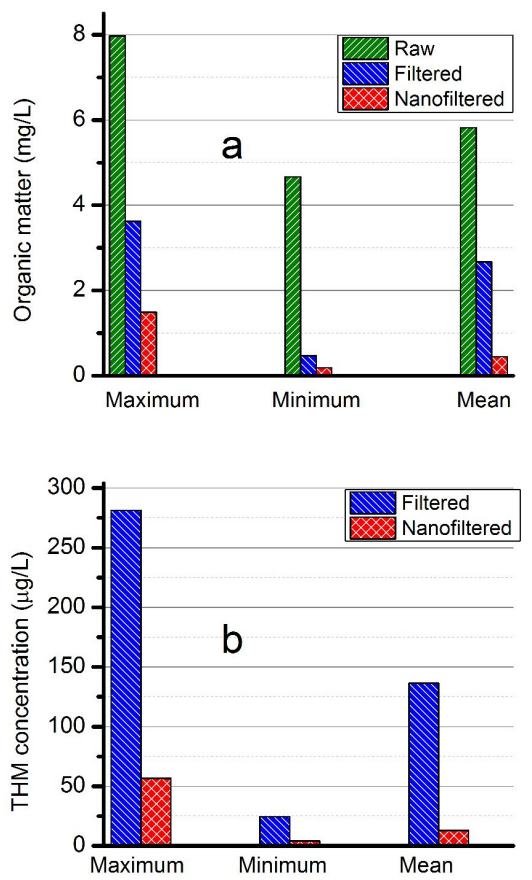

Fig. 4. Comparison of maxima, minima and mean values of: a) Oxidability and b) THM content, in raw, filtered and nanofiltered water.

As expected, the situation is significantly more favorable after nanofiltration. In this regard, the average content of organic matter in water after nanofiltration is only $19 \%$ compared to the filtered water $(0.3 \mathrm{mg} / \mathrm{L}$ vs. $1.6 \mathrm{mg} / \mathrm{L})$. Furthermore, after nanofiltration the maximum does not exceed $45 \%$ of that corresponding to filtration $(1.0 \mathrm{mg} / \mathrm{L}$ versus 2.2 $\mathrm{mg} / \mathrm{L}$ ). Also, as a side effect, the incidence of odor-taste in treated water was zero during the period studied.

In Figure $4 \mathrm{~b}$ the extreme values of THM in chlorinated water after nanofiltration and after filtration can be observed. Again, and which involved the main objective pursued, the situation is very different in the two cases. THM generated in the water after nanofiltration do not exceed the parametric limit of $100 \mu \mathrm{g} / \mathrm{L}$, nor in average value $(13 \mu \mathrm{g} / \mathrm{L})$ nor in the maximum value $(<60 \mu \mathrm{g} / \mathrm{L})$. Finally, the generation of THM in chlorinated filtered water, even on average value, amply exceeded the imperative limit $(100 \mu \mathrm{g} / \mathrm{L})$.

As supplementary information, Figure 5 shows the weekly evolution of THM levels in the produced water after nanofiltration along the study. It is observed that after relatively high values at the beginning of the installation of the system (which coincided with a situation of poor quality of the raw water from the reservoir) its behavior exhibits a sustained maintenance of very low THM concentrations after the integrated treatment. Thus, after the first five weeks of implementation of nanofiltration, the total THM levels were normally lower than $20 \mu \mathrm{g} / \mathrm{L}$. 


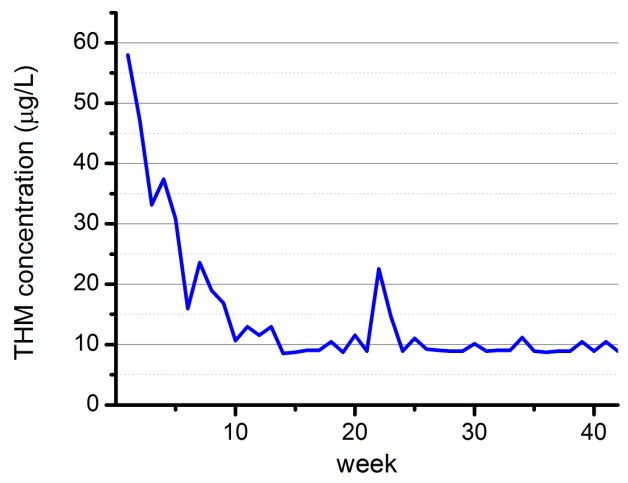

Fig. 5. Evolution of the total THM after the full nanofiltration system is operating (weekly sampling).

In summary, these results extensively justify the adopted system as the solution to the problem of inadequate THM levels.

As a positive additional aspect of system performance, full nanofiltration system always guaranteed the absence of total coliforms and Escherichia coli in water throughout the study.

Further, the full nanofiltration system led a significantly lowering in the salt content. Thus, the average value of the conductivity of the filtered water was reduced to $65 \%$ (from $274 \mu \mathrm{S} / \mathrm{cm}$ to $177 \mu \mathrm{S} / \mathrm{cm}$ ), while the hardness decreased by $54 \%\left(99 \mathrm{mg} / \mathrm{L}\right.$ versus $53 \mathrm{mg} / \mathrm{L}$ of $\left.\mathrm{CaCO}_{3}\right)$ and bicarbonate in $63 \%(114 \mathrm{mg} / \mathrm{L}$ vs. $72 \mathrm{mg} / \mathrm{L})$.

Finally, although the full nanofiltration system does not significantly reduce the average content of iron and manganese, a decrease in the obtained maximum values of these metals must be noted in the treated water. The maximum manganese concentration never exceeded the parametric value required, condition that was not satisfied only by filtration. Similarly, no remarkable improvement was observed in relation to the contents of aluminum, nitrites or ammonium, although these parameters were not among the primary objectives pursued.

\section{CONCLUSSIONS}

The application of a complementary system of nanofiltration to the water produced after pre-oxidation and closed sand filter coagulation in a small supply is able to maintain THM concentrations far below required, with mean values of $13 \mu \mathrm{g} / \mathrm{L}$, and with tips, $58 \mu \mathrm{g} / \mathrm{L}$, well below the maximum limited $(100 \mu \mathrm{g} / \mathrm{L})$.

The full nanofiltration treatment installed is integrated by a pre-filtration system, an adsorption system, a post-filtration system, and finally, the nanofiltration system.

Nanofiltration system, apart from the production of water with lower salt content than the starting water, produced water with very low concentrations of organic matter (average value of $0.3 \mathrm{mg} / \mathrm{L}$ ) and therefore with minimum odor-taste incidents. The production of water with levels of Mn always according to that imperative in Spanish normative $(<50 \mu \mathrm{g} / \mathrm{L})$, should also be noted. Finally, the system is able to produce treated drinking water with an excellent microbiological quality in all situations which represents a relevant yielding for it.

\section{ACKNOWLEDGMENT}

To Juan Sánchez Bejarano, Technician of the Engineering and Maintenance Department of EMACSA by the information provided.

\section{REFERENCES}

[1] J. M. Rodríguez Mellado, R. Marín Galvín, Fisicoquímica de aguas, Díaz de Santos, Madrid, 1999

[2] R. Marín Galvín, Fisicoquímica y microbiología de los medios acuáticos. Tratamiento y control de calidad de aguas, Díaz de Santos, Madrid, 2003

[3] World Health Organization, Guidelines for drinking water qualityRecommendations, Vol. 1, $3^{\text {rd }}$ ed., Genéve, 2006.

[4] W. Stumm, J. J. Morgan, Aquatic chemistry: chemical equilibria and rates in natural waters, Wiley Interscience, New York, 1980.

[5] G. Tchobanoglous, Water Quality: characteristics, modeling, modification, Adisson-Wesley Pub. Co., Reading (Mass.), 1985.

[6] Degrémont, Meménto technique de l'eau. Degrémont, París, 1989

[7] F. J. Rodríguez Vidal, Procesos de potabilización del agua e influencia del tratamiento de ozonización, Díaz de Santos, Madrid, 2003

[8] F. Ramírez Quirós, "Desinfección del agua con cloro y cloraminas", Técnica Industrial, No. 260, pp. 55-63, 2005

[9] R. Marín Galvín, "Implicaciones del Decreto 70/2009 de la Junta de Andalucía: práctica de la cloraminación como desinfección final del agua de Córdoba", RETEMA: Revista Técnica de Medio Ambiente, No. 146, pp. 74-84, 2010

[10] H. H. Hahn, R. Klute (Eds), Chemical water and wastewater treatment: Proceedings of the 4th Gothenburg Symposium 1990, October 1-3, 1990, Madrid, Spain, Springer-Verlag, Darmstad, 1990

[11] F. M. M. Morel, J. G. Hering, Principles and Applications of aquatic chemistry, Wiley and Sons Inc., New York, 1993.

[12] American Water Works Association (AWWA), Tratamiento del agua por procesos de membrana. Principios, procesos y aplicaciones, McGraw-Hill Interamericana de España, Madrid, 1999.

[13] R. Marín Galvín, "Evolution of water quality in a reservoir used for human consumption: Guadalmellato (1980-1991), (I). Hydric behaviour, temperature, oxygen, $\mathrm{pH}, \mathrm{Fe}, \mathrm{Mn}$, and Ammonia", Eur. Water Pollut. Contr., Vol. 3, No. 3, pp. 15-29, 1993.

[14] R. Marín Galvín, "Evolution of water quality in a reservoir used for human consumption: Guadalmellato (1980-1991), (II). Transparency, colour, turbidity, conductivity, organic matter, phosphorus,aluminium and total coliforms", Eur. Water Pollut. Contr., Vol. 3, No. 4, pp. 36-43, 1993.

[15] R. Marín Galvín, Análisis de aguas y ensayos de tratamiento: principios y aplicaciones, Gestió i Promoció Editorial-GPE, S.A., Barcelona, 1995.

[16] American Water Works Association (AWWA), Standard Method for the examination of water and wastewater, 22nd ed., American Public Health Association (APHA), American Water Works Association (AWWA) \& Water Environment Federation (WEF) 2012.

[17] Kärcher $^{\mathrm{TM}}$. Technical information supplied by the supplier of the industrial system Kärcher ${ }^{\mathrm{TM}}$ WPC 100 FW-A-RO. 